\title{
The Effect of Farm Location on Physiological Conditions and Productivity of Friesian-Holstein Crossbreed Cows
}

\author{
Endang Widiastuti ${ }^{1}$, Kustono Kustono ${ }^{2}$, Adiarto Adiarto $^{2}$ and Nurliyani ${ }^{2}$ \\ 1. Faculty of Animal and Agriculture Sciences, Diponegoro University Tembalang Campus, Semarang 50275, Central Java, \\ Indonesia \\ 2. Faculty of Animal Science, Gadjah Mada University, Jl. Fauna Bulaksumur, Yogyakarta 55281, Indonesia
}

\begin{abstract}
Farm location is an important factor in dairy farms, as it is closely associated with temperature and humidity that are crucial factors of influencing the physiological conditions and productivity of cows especially during the lactation period. The purpose of this study was to determine the effect of farm location on the physiological conditions and productivity of cows. The study was involved in 18 lactating Friesian-Holstein crossbreed cows in three farmer groups, i.e., Nangkasawit, Plalangan and Sumurejo. Temperature and humidity of the environment, rainfall and physiological conditions of cows (respiration rate, pulse, rectal temperature, total erythrocytes, hemoglobin and hematocrit) were observed. No influence $(P>0.05)$ of farm location on the parameters was observed, except for milk production $(P<0.05)$. In conclusion, farm location had no impact on the physiological conditions of Friesian-Holstein crossbreed cows in the district Gunungpati Semarang, Central Java, Indonesia.
\end{abstract}

Key words: Environment, farm location, physiological response, milk yield.

\section{Introduction}

Environment plays an important role in the productivity of dairy cows. Any change in the environment may influence the physiological conditions that in turn affect the productivity of the cows. Of the environmental factors, temperature and humidity are the most crucial especially for the cows during the lactation period. Cows will respond to the change of environmental temperature and humidity by adjusting their physiological processes. When the internal condition is maintained, cows can survive and yield milk properly. Conversely, cows may experience stress when they could not maintain their internal body condition, i.e., body temperature. In this case, milk production will be attenuated as more energy is allocated to maintain the homeostatic condition of the cows [1].

To avoid stress due to environmental pressure, cows should be reared in the thermoneutral/comfort

Corresponding author: Endang Widiastuti, M.Sc., research field: animal physiolgy. E-mail: endwidia@yahoo.co.id. zone (metabolic rate is minimal in the range of ambient temperatures and the range corresponds to minimal thermal stress). Cows produce milk optimally when they are kept in the environment with temperature of $18.3^{\circ} \mathrm{C}$ and humidity of 55\% [2]. In the tropical region, such as Indonesia, the comfort zone for dairy cows may be a problem due to high environmental temperature and humidity, which range from $24{ }^{\circ} \mathrm{C}$ to $34{ }^{\circ} \mathrm{C}$ and $60 \%$ to $90 \%$, respectively. Such conditions may induce stress in dairy cows and thus lead to: (1) drop in feed intake; (2) increase in water intake; (3) disturbed metabolism and hormone concentration in the blood; (4) increase in body temperature, respiration rate and pulse; (5) changes in behaviour of cows [3, 4]. All these physiological and behavioural changes may negatively affect the productivity of the cows.

It has been known that farm location may determine the environmental temperature and humidity. Hence, the purpose of this study was to determine the effect of farm location on the physiological conditions of cows, which in turn affected the production and 
quality of milk.

\section{Materials and Methods}

Study was carried out from June 2012 to February 2013 at three farmer groups in district Gunungpati, Semarang, Central Java Province, Indonesia, i.e., farmer group Pangudi Mulya at Nangkasawit village, farmer group Ngudi Rahayu at Plalangan village and farmer group Rejeki Lumintu at Sumurejo village. These different locations with different temperature and humidity represented the three treatments. Each treatment consisted of six lactating Friesian-Holstein crossbreed cows.

The parameters observed were the physiological and haematological conditions as well as milk production. Physiological conditions included respiration rate, pulse frequency and rectal temperature. Data of physiological conditions were collected three times, i.e., in the morning before milking, noon and afternoon. Data were averaged and used in the statistical analysis. The haematological conditions of dairy cows included the number of erythrocytes, hemoglobin and hematocrit levels. Blood was collected in the morning at the end of study. Milk was collected from the cows of three farmer groups. Milk production was corrected for 305 days of milking. Ambient temperature and humidity were measured to calculate the temperature humidity index (THI). Data were analyzed by using randomized block design [5], which comprised three groups of farm locations and six replications.

\section{Results and Discussion}

District Gunungpati where the farms situated has a height of 241-384 $\mathrm{m}$ above the sea and average annual rainfall of 2,440 $\mathrm{mm}$. The range of temperature and humidity in Nangkasawit were $22-33{ }^{\circ} \mathrm{C}$ and 55\%-90\%, in Plalangan 20-30 ${ }^{\circ} \mathrm{C}$ and 60\%-95\%, and in Sumurejo 22-33 ${ }^{\circ} \mathrm{C}$ and $52 \%-90 \%$, respectively. Based on these data, the THI in Nangkasawit was 79, in Plalangan 75 and in Sumurejo 79. This condition indicated that the cows in the current study experienced mild stress [6].

The mean physiological parameters of the cows are presented in Table 1. In general, the effect of farm locations on the physiological conditions of the cows was not seen in this study. The lack of difference in term of THI may explain this result.

It has been acknowledged that the respiration rate of cows is affected by the temperature and humidity of the environment. It was mentioned that the respiration rate of cows is 20, 50-60 and 100 breaths/min when they are reared at $<20{ }^{\circ} \mathrm{C}, 25{ }^{\circ} \mathrm{C}$ and $32{ }^{\circ} \mathrm{C}$, respectively [1]. This previous study is in accordance with the result of the current study; in the current study, the respiration rate of cows reared at $22-33^{\circ} \mathrm{C}$ was 46-49 breaths/min. Overall, the higher the temperature and humidity of the environment are, the higher respiration rate of the cows will be. The increased respiration rate is one of the homeostatic mechanism to regulate the body temperature (enhance the heat dissipation from the cows) so that the normal internal body temperature can be maintained. It was noted that the normal body temperature is crucial for the normal physiological processes. In general, the change in respiration rate is in parallel with the change in pulse. However, the respiration rate (and rectal temperature) appeared to be more sensitive as the indicators of heat stress than pulse rate in dairy cows [7].

Table 1 Respiration rate, pulse and rectal temperature of cows.

\begin{tabular}{llll}
\hline \multirow{2}{*}{ Parameters } & \multicolumn{3}{c}{ Farm locations } \\
\cline { 2 - 4 } & Nangkasawit & Plalangan & Sumurejo \\
\hline Respiration rate (breaths/min) & 49.37 & 46.91 & 49.86 \\
Pulse (beats/minute) & 55.33 & 55.85 & 62.50 \\
Rectal temperature $\left({ }^{\circ} \mathrm{C}\right)$ & 37.68 & 37.32 & 37.81 \\
\hline
\end{tabular}


Table 2 Haemoglobin, total erythrocytes and haematocrit of cows.

\begin{tabular}{llll}
\hline \multirow{2}{*}{ Parameters } & \multicolumn{3}{c}{ Farm locations } \\
\cline { 2 - 4 } & Nangkasawit & Plalangan & Sumurejo \\
\hline Haemoglobin $(\mathrm{g} / 100 \mathrm{~mL})$ & 9.28 & 9.08 & 9.03 \\
Erythrocytes $\left(\times 10^{3}\right.$ cells $\left./ \mathrm{mm}^{3}\right)$ & 3.36 & 3.62 & 3.48 \\
Haematokrit $(\%)$ & 28.76 & 28.11 & 29.64 \\
\hline
\end{tabular}

Table 3 Milk yield and microbial content in the milk.

\begin{tabular}{llll}
\hline \multirow{2}{*}{ Parameters } & \multicolumn{3}{l}{ Farm locations } \\
\cline { 2 - 4 } & Nangkasawit & Plalangan & Sumurejo \\
\hline Milk yield (L/lactation) & $2,094.60^{\mathrm{b}}$ & $2,820.00^{\mathrm{b}}$ & $4,446.90^{\mathrm{a}}$ \\
Microbial content $(\log$ CFU/mL) & $5.96^{\mathrm{a}}$ & $6.04^{\mathrm{a}}$ & $5.85^{\mathrm{b}}$ \\
\hline
\end{tabular}

In this study, the effect of farm location on the haematological parameters of the cows was not observed (Table 2). Again, the lack of difference of THI among the farm location may be responsible for this result. In general, the haematological parameters of the cows were within the normal range $[8,9]$. This is slightly contradictory to the data of THI that suggests that cows experienced mild stress. Collection of the blood was in the end of the study (February 2013), because it is the peak of rainy season in Indonesia. It is noted that on January and February, the average temperature in Indonesia is below $30{ }^{\circ} \mathrm{C}$. Thus, cows did not experience heat stress during the blood collection.

Milk production differed $(P<0.05)$ among the cows from different location of the farms (Table 3). This result was in contrast to the data of physiological and haematological parameters as well as to the data of THI above. In this notion, the difference in milk production was more likely due to the other factors than the environment, such as nutrition. In addition, the breed of cows, the hygiene of environment and the cow itself may influence the milk production [10]. In this current study, the authors also noticed that milk from Sumurejo had the lowest microbial content (Table 3). The low content of microbes in the milk may indicate that the cows from Sumurejo had low prevalence of subclinic mastitis, and therefore yielded more milk than the other cows.

Milk produced by the cows from Sumurejo village had lower microbial content as compared with that produced from Nangkasawit and Plalangan village. The microbial content in milk produced by the cows from Sumurejo and Nangkasawit is still acceptable by the Indonesian national standard (maximum $6.00 \mathrm{log}$ $\mathrm{CFU} / \mathrm{mL}$ ), whereas the milk produced by the cows from Plalangan is not acceptable by the Indonesian national standard. The number of microbes in the milk is affected by several factors, such as the hygiene of the cows and house, milking equipments, etc.. Water, soil and vegetation are other sources of microbial contamination for the milk [11]. The water used for the cows in Plalangan village is the river origin, and thus the potential microbial contamination seems to a greater extent than that in Sumurejo dan Nangkasawit village that get water from the well.

\section{Conclusions}

Although the THI in the district Gunungpati Semarang, Central Java, Indonesia may induce mild stress in the cows, this location may be used to rear the cows for producing the milk. Other than farm location, the nutrition, management, hygiene of the cows, house and milking equipments may influence the production and quality of the milk in the district Gunungpati Semarang, Central Java, Indonesia.

\section{References}

[1] Kadzere, C. T., Murphy, M. R., Silanikove, N., and Maltz, E. 2002. "Heat Stress in Lactating Dairy Cows: A Review.” Livestock Production Science 77 (1): 59-91.

[2] Berman, A. 2005. "Estimates of Heat Stress Relief Needs for Holstein Dairy Cows.” J. Anim. Sci. 83 (6): 1377-84. 


\section{Friesian-Holstein Crossbreed Cows}

[3] McDowell, R. E. 1972. Improvement of Livestock Production in Warm Climates. San Fransisco: W. H. Freeman and Company.

[4] Yani, A., and Purwanto, B. P. 2006. "The Effect of Microclimate toward the Physiology Response of Friesian-Holstein Crossbreed and Environment Modification to Increase Its Productivity.” Media Peternakan 29 (1): 35-46.

[5] Steel, G. D., and Torrie, G. H. 1987. Priciples and Procedures of Statistics. Los Angeles: McGraw Hill Inc..

[6] Moran, J. 2005. Tropical Dairy Farming: Feeding Management for Small Holder Dairy Farmers in the Humid Tropics. USA: Landlinks Press.

[7] Lemerle, C., and Goddard, M. E. 1986. "Assessment of Heat Stress in Dairy Cattle in Papua, New Guinea.” Trop. Anim. Health Prod. 18 (4): 232-42.

[8] Agustin, F., Toharmat, T., Evvyernie, D., Taniwiryono, D., and Tarigan, S. 2012. "Blood Profile of Lactating
Cows Supplemented with Organic Chromium and Ganoderma lucidum.” Pakistan Journal of Nutrition 11 (10): 893-9.

[9] Katsoulos, P. D., Roubies, N., Panousis, N., Christaki, E., Karatzanos, P., and Karatzias, H. 2005. "Effects of Long Term Feeding Dairy Cows on a Diet Supplemented with Clinoptilolite on Certain Haematological Parameters.” Vet. Med. Czech 50 (10): 427-31.

[10] Anggraeni, A. 2007. "The Influence of Age, Season and Year of Calving toward Friesian Holstein Fresh Milk Production in an Intensive and Semi Intensive Treatment in Banyumas District.” Presented at a Seminar of Animal Science and Veterinary Technology, Animal Science Research and Development Center, Bogor.

[11] Hayes, M. C., and Boor, K. 2001. "Raw Milk and Fluid Milk Products.” In Applied Dairy Microbiology, 2nd ed., edited by Marth, E. H., and Steele J. L. New York: Marcell Dekker Inc., 59-76. 